\title{
Betekintés az idiopathiás inflammatorikus myopathiában szenvedő betegek gyógytornájába
}

\author{
Váncsa Andrea dr. \\ Debreceni Egyetem, Népegészségügyi Kar, Fizioterápiás Tanszék, Debrecen
}

\begin{abstract}
Idiopathiás inflammatorikus myopathiában szenvedő betegeknél a jelenleg alkalmazott gyógyszeres kezelés mellett izomkárosodás és egészségromlás alakul ki. A gyógytornának az izomteljesítményre, az aerob kapacitásra és az egészségre gyakorolt jótékony hatásait vizsgálták krónikus polymyositises és dermatomyositises betegeknél, és a kisebb mértékben aktív betegségben, inclusion body myositisben szenvedő betegeknél. Randomizált vizsgálatok arra utalnak, hogy a fokozott aerob kapacitás egészségjavulással és a klinikai betegségaktivitás csökkenéssel jár együtt. Jelenleg kutatják azokat a mechanizmusokat, amelyek a gyógytornának a vázizomzatra kifejtett hatásai mögött állnak (fokozott mitokondriális kapacitás és kapillárisdenzitás, csökkent laktátszint, aerob fenotípusú génaktiváció, izomnövekedési programok, gyulladáshoz kapcsolható gének csökkent kifejeződése). Összességében a gyógytorna hozzájárul mind a szisztémás, mind az izmon belüli adaptációhoz. Aktív betegségben és inclusion body myositisben szenvedő betegeknél a gyógytorna hatásának tanulmányozására randomizált klinikai vizsgálatok szükségesek. Orv. Hetil., 2016, 157(39), 1557-1562.
\end{abstract}

Kulcsszavak: idiopathiás inflammatorikus myopathiák, polymyositis, dermatomyositis, inclusion body myositis, aerob kapacitás, aerob metabolizmus, adaptáció, gyógytorna, vázizomzat, betegségaktivitás, izomfunkció

\section{Insight into the training of patients with idiopathic inflammatory myopathy}

Using current recommended treatment, a majority of patients with idiopathic inflammatory myopathy develop muscle impairment and poor health. Beneficial effects of exercise have been reported on muscle performance, aerobic capacity and health in chronic polymyositis and dermatomyositis, as well as in active disease and inclusion body myositis to some extent. Importantly, randomized controlled trials indicate that improved health and decreased clinical disease activity could be mediated through increased aerobic capacity. Recently, reports seeking pathomechanisms of the underlying effects of exercise on skeletal muscle indicate increased aerobic capacity (i.e. increased mitochondrial capacity and capillary density, reduced lactate levels), activation of genes of aerobic phenotype and muscle growth programs and down regulation of genes related to inflammation. Exercise contributes to both systemic and withinmuscle adaptations demonstrating that it is fundamental for improving muscle performance and health in patients with idiopathic inflammatory myopathy. There is a need for randomized controlled trials to study the effects of exercise in patients with active disease and inclusion body myositis.

Keywords: idiopathic inflammatory myopathies, polymyositis, dermatomyositis, inclusion body myositis, aerobic capacity, aerobic metabolism, exercise adaptations, physical exercise, skeletal muscle, disease activity, muscle function

Váncsa, A. [Insight into the training of patients with idiopathic inflammatory myopathy]. Orv. Hetil., 2016, 157(39), $1557-1562$.

(Beérkezett: 2016. június 22.; elfogadva: 2016. július 22.)

\section{Rövidítések}

ATP = adenosin-triphosphate CK $=$ creatinin kinase $;$ CS $=$ cit ric synthase; $\mathrm{DM}=$ dermatomyositis; $\mathrm{ER}=$ endoplasmaticus reticulum; $\mathrm{HAD}=$ hydroxyacyl-CoA dehydrogenase; $\mathrm{HAQ}=$ health assessment questionnaire; IBM = inclusion body myositis; IIM = idiopathic inflammatory myopathy; ILD = interstitial lung disease; IMACS = International Myositis Association Clinical Studies Group; MMT = manual muscle test MRI = magnetic resonance imaging; MWT $=$ min. walking test; PM/DM = polymyositis $/$ dermatomyositis; VAS = visual analogue scale; VAT $=$ ventilator anaerobic threshold; VRM = voluntary repetition maximum 
A legprominánsabb klinikai tünet minden myositises alcsoportban a szimmetrikus proximális izomgyengeség, amely csökkent izomellenálló képességhez vezet, heteken, hónapokon át tartó progresszív hanyatlással $[1,2]$. Ez a betegek szignifikáns mozgásképtelenségét okozza. $\mathrm{Az}$ izomgyengeség ismert rizikófaktora a posturalis instabilitásnak és eséseknek. A gyógytorna célja fejleszteni az izomteljesítményt a betegség exacerbatiója nélkül. A célzott gyógytorna nemcsak biztonságos beavatkozás, és nemcsak az izomerőt és az állóképességet javítja, hanem antiinflammatorikus, antifibrotikus és pozitív metabolikus hatásai is vannak.

Nagy dózisú kortikoszteroidok és immunszuppresszív szerek alkalmazása fokozott izomteljesítményhez vezet, néhány esetben a betegek visszanyerik a kiindulási izomfunkciójukat. Krónikus polymyositises és dermatomyositises betegeknél aktív betegségben és inclusion body myositisben (IBM) szenvedő betegeknél is bizonyított a gyógytorna hatásossága az izomteljesítményre, az aerob kapacitásra és az egészségre. Randomizált klinikai vizsgálatok (RCTs) utalnak arra, hogy ezeknél a betegeknél az egészség javulása és csökkent klinikai betegségaktivitás fokozott aerob kapacitáshoz köthető. Jelenleg a kutatók keresik a mechanizmust, amely a gyógytorna hatása mögött áll a szkeletális izomzatban (idő előtt fokozott mitokondriális kapacitás és kapillárisdenzitás, csökkent laktátszint), aerob fenotípusú gének aktivációja és izomnövekedési programok, azon gének downregulációja, amelyek felelősek a gyulladásért az izomzatban. Összességében a gyógytorna hozzájárul mind a szisztémás, mind az izomzaton belüli adaptációhoz, demonstrálva azt, hogy alapvető az izomteljesítmény javításában és az idiopathiás inflammatorikus myopathiában (IIM) szenvedő betegek egészségének fenntartásában. Szükség van további randomizált kontrollvizsgálatokra annak tanulmányozására, hogy a gyógytorna milyen hatással van aktív betegségben és IBM esetén.

\section{Kóros izomteljesítményt okozó mechanizmusok IIM-ben}

Akut betegségfázisban mind a szisztémás, mind a lokális gyulladás a vázizomzatban kóros izomteljesítményhez vezet PM/DM-es betegekben. Habár a mechanizmus, amely tartós izomkárosodáshoz vezet, bizonytalan olyan betegeknél, akiknél nyilvánvaló gyulladás vagy izomrostatrófia nincs.

Másodlagos károsodás a korábbi gyulladásos miliő miatt, a gyógyszeres kezelés mellékhatásai és/vagy fizikális inaktivitás mind hozzájáruló tényezők [3]. A kóros vázizom-teljesítmény nem korrelál direkt módon az immunológiai háttérrel, amely nem immunmechanizmusok szerepét is sugallja, mint az ER-stressz, hypoxia és autophagia [3]. Az izomrost-degeneráció, vázizom-atrófia és károsodott izomregeneráció PM/DM-es betegekben szintén hozzájárul a tartós izomgyengeséghez [4].
Másodlagos aerob metabolikus diszfunkció - amelyet a hypoxia talaján kialakuló proinflammatorikus környezet indukál - vezet a kóros izomfunkciókhoz [3, 5]. A metabolikus diszfunkció, amely károsodott aerob anyagcseréhez vezet, befolyásolja az intrinszik izomfunkciókat és korai izomkifáradást okoz. Mind a mitokondriális, mind a kapilláris funkcionalitás követelménye az aerob metabolikus kapacitásnak a vázizomzatban, és kapcsolódik az állóképességi teljesítményhez. Számos metabolikus diszfunkciót írtak le IIM-es betegekben, a tárolt ATP és foszfokreatin alacsony szintjét az izomzatban csökkent fáradási ellenállással és kevesebb aerob slowswitch I-es típusú izomrosttal. Az aerob energia metabolizmusában is találtak eltéréseket PM/DM-es betegek esetén mind a mitokondriális és kapilláris patológiát illetően. Két vizsgálatban, laktátszintmérés történt fizikai aktivitás után. Egy vizsgálatban krónikus PM/DM-ben szenvedő betegek esetén a vázizomzat laktátkoncentrációját mérték $\mathrm{VO}_{2 \max } 65 \%$-án kimerülésig történő szobakerékpározás után, összehasonlítva az egészséges kontrollokkal [6]. A laktátkoncentráció - mint az anaerob metabolizmus markere - hasonló volt a betegekben és egészséges kontrollokban annak ellenére, hogy az egészséges kontrollok dupla annyi ideig bicikliztek [6, 7]. Egy másik vizsgálatban a szérumlaktátszintet mérték PM/ DM-ben szenvedő betegeknél aktív és krónikus fázisban, összehasonlítva az egészséges kontrollokkal [8]. A betegeknél magasabb volt a szérumlaktátszint, mint az egészséges kontrolloknál, annak ellenére, hogy rövidebb ideig tornáztak [8]. Összességében ezek az eredmények arra utalnak, hogy a megváltozott aerob metabolikus kapacitás a vázizomzatban hozzájárulhat a tartós izomkárosodáshoz, korai kezdetú kifáradáshoz és az alacsony aerob kapacitáshoz PM/DM-ben szenvedő betegek esetén $[6,9]$. Someya és Mugii értékelték a gyógytorna-teljesítményt olyan, DM-ben és ILD-ben szenvedő betegeknél, akiknél klinikai izomgyengeség nem volt jelen, és azt tapasztalták, hogy a tornateljesítményt nem korlátozza a károsodott tüdőfunkció, de annál inkább az izomkárosodás, még akkor is, ha aszimptomatikus [10].

IBM-ben a patofiziológia kevésbé ismert, de úgy tünik, hogy mind az autoimmun, mind a degeneratív utak hozzájárulnak az izomkárosodáshoz. Mostanában közöltek vázizomellenes autoantitesteket IBM-ben. Ezek az antitestek kapcsolatot sugallnak az autoimmunitás és IBM-ben jelentős degeneratív sajátosságok között, és abnormális nukleinsav-metabolizmusra utalnak, amely hozzájárul az izomrost-károsodáshoz ezeknél a betegeknél. Magnetic resonance imaging (MRI) vizsgálatok eredménye azt mutatja, hogy az IBM-es betegekben az izomszövet helyét zsírszövet foglalja el [11].

\section{Gyógytorna idiopathiás inflammatorikus myopathiákban}

Korábban az IIM-ben szenvedő betegek esetén felmerült annak a lehetősége, hogy a gyógytorna az izomgyul- 
ladást fellobbantja, így az izomgyengeséget fokozza. Számos tanulmány sugallja, hogy a felügyelet mellett végzett gyógytorna biztonságos ezeknek a betegeknek a terápiájában, mind stabil és néhány esetben akut IBM-es esetekben is $[7,12]$. Megelőzi az izomatrófia kialakulását, amelyet az izomgyulladás, fizikális inaktivitás és szisztémás kortikoszteroidkezelés okoz [13]. Habár IIM-es betegeknél további randomizált kontrollvizsgálatok szükségesek ennek validálására. Különösen akut PM/DM-es betegek esetén és IBM-ben [12, 14], illetve szükség van a háttérben fekvő mechanizmusok pontosabb definiálására.

A szisztémás és az izmon belüli adaptáció az izomkontrakciók ismétlődő sorozataira függ a frekvenciától, intenzitástól és az időtartamtól. Egészségesekben az aerob gyakorlatok az aerob kapacitást fejlesztik mind szisztémásan (teljestest-kapacitás, $\mathrm{VO}_{2 \max }$ ), mind lokálisan a vázizomzatban, fóleg a fokozott kapilláris és mitokondriális funkcióval.

Igazolt, hogy IIM-es betegeknél a rezisztenciagyakorlatok izom-hipertrófiához vezetnek, és fokozott izomerőhöz, illetve downreguláló funkciójuk is van a szisztémás és lokális gyulladásra az izomzatban [13]. Összesen nyolc cikket publikáltak ezzel kapcsolatban. Három közleményben akut PM/DM-es eseteket vizsgáltak, négy esetben randomizált kontroll- vagy kontrollált vizsgálatokat végeztek ezzel kapcsolatban, és kettő a hosszú távú hatásokat vizsgálta. A tornaprogram felügyelet mellett végzett állóképességi/aerob gyakorlatokat tartalmazott 7 esetben, ahol 2 szintén tartalmazott erősítéses gyakorlatokat, míg összesen egy vizsgálat tartalmazott otthoni rezisztencia-tornaprogramot.

Fontos a még specifikusabb értékelése annak a mechanizmusnak, amely a gyógytorna hatásossága mögött áll [14].

\section{A gyógytorna hatása az izomteljesítményre és egészségre}

Öt vizsgálat igazolt javult izomteljesítményt krónikus fázisban lévő PM-es vagy DM-es betegek esetén állóképességi, illetve aerob gyakorlatok során.

A két multicentrikus randomizált kontroll- és a kontrollált vizsgálatban mind az izomerő ( 5 VRM a térd extensor izmokban mérve), mind a kimerülésig történő szoba-kerékpározási idő a maximális $\mathrm{O}_{2}$-felvétel 65\%-án szignifikánsan javult a tornacsoportban, míg a kontrollcsoport eredményei változatlanok voltak [7]. A tornacsoportban ebben a 3 vizsgálatban a betegek ugyanolyan felügyelet mellett végzett állóképességi tornán vettek részt heti 3 alkalommal 12 héten keresztül. A tornaprogram tartalmazott egy 1 órás szoba-kerékpározást, a $\mathrm{VO}_{2 \max } 70 \%$-án 30 percig. Ezt a térdextensorok 20 perces állóképességi tornája követte 1 VRM 30-40\%-án. A kontrollcsoport fizikai aktivitása változatlan volt a 12 hét során. Ennek az állóképességi tornaprogramnak szintén voltak szisztémás hatásai, mint a szignifikánsan fokozott $\mathrm{VO}_{2 \max }$ a tornacsoportban, összehasonlítva a kontrollcsoporttal [7].

Egy esetismertetésben, amelyet Dalise és mtsai közöltek, a beteg 5 hetes, felügyelet mellett végzett aerob gyakorlaton vett részt hetente 5 alkalommal, amely fokozott izomerôt eredményezett 3-4 izomcsoportban. Bertolucci és mtsai által végzett nyílt vizsgálatban 4 beteg vett részt egy 6 hetes, felügyelet mellett végzett aerob gyakorlaton. A heti 3 alkalommal végzett 10 perces járásteszt (10 MWT) javulást mutatott mind a négy betegnél. A 4-ből 3 beteg állapota javult a 6 perces járásteszt során (6 MWT), míg a másik esetismertetés adatai szerint a 6 perces járásteszt 5 hét aerob gyakorlat után nem eredményezett változást [8].

Krónikus PM/DM-es betegeken két vizsgálat mérte fel az állóképességi vagy aerob torna hatékonyságát a betegek egészségi állapotára vonatkozóan. Az esetismertetés során a beteg állapota az SF-36 fizikális doménjeit nézve javult. Egy multicentrikus, randomizált kontrollvizsgálatban 12 hetes állóképességi torna után mind az SF-36 fizikális, mind a vitális doménjei javulást mutattak, de ez nem történt meg a kontrollcsoportban. Az egészségjavulás szorosan összefüggésben volt a $\mathrm{VO}_{2 \max }$-mal, ami arra utal, hogy a javult egészségi állapot összefüggésben van a javult $\mathrm{O}_{2}$-felvevő képességgel. A randomizált kontrollvizsgálat egy 12 hetes állóképességi torna hosszú távú hatásait vizsgálta egyéves kiterjesztés során. A betegek a tornacsoportban megőrizték a javult izomteljesítményt az l éves utánkövetés során, míg a kontrollcsoport esetében nem volt változás a kiindulási paraméterekhez képest, ellenkezőleg, az egyéb paraméterek megfeleltek a kiindulási értékeknek. Ezek az eredmények alátámasztják a fizikailag aktív életvitel fontosságát, beleértve az állóképességi tornát a krónikus PM/DM-ben szenvedő betegek egészségének fenntartásában. Három vizsgálat - a PM/DM-es betegeket is beleértve - demonstrálta az akut betegségfázisban az izomteljesítmény javulását $[7$, $15,16]$.

Egy randomizált klinikai vizsgálat értékelte a gyógytorna hatékonyságát akut PM/DM-ben. Ez a vizsgálat értékelte az otthoni rezisztencia-tréningprogramot mind rövid, mind hosszú távon [7]. A kezelés alatt a betegek nagy dózisú kortikoszteroidterápiában részesültek, egyéb immunszuppresszív szerekkel kiegészítve. Négyhetes terápia után a tornacsoport elkezdte az ellenállással szemben végzett otthoni tornaprogramot, a proximális izmokat tornáztatva a gravitáció ellenében extra súlyokkal (10 alkalommal). A betegek ezt a tornaprogramot végezték 5 napig 12 héten keresztül. Telefonos konzultáció hetente történt. Ez után 12 hetes, felügyelet nélkül végzett torna következett, heti két alkalommal. A kontrollcsoport telefonos konzultáció nélkül vett részt 24 héten keresztül egy ROM (range of motion) tornaprogramban, heti 5 alkalommal [7]. Mindkét csoport esetében az izomteljesítmény szignifikánsan javult a funkcionális index és aerob kapacitás alapján futópadteszttel felmérve, ellentétben azzal, hogy az egészség tekinteté- 
ben csak minor változások történtek (Nottingham Health Profile) a 24 hetes utánkövetés során. Egy kétéves utánkövetés alapján a betegek többsége a tornacsoportban egy fizikailag aktív életstílust tudott fenntartani rendszeres tornával, míg a kontrollcsoportban csak két beteg volt fizikálisan aktív. A javulás az izomteljesítményt és aerob kapacitást tekintve 1 évig volt fenntartható, míg a tornacsoport esetén a javulás 2 évig volt fenntartható. A felügyelet mellett végzett aerob torna kombinálva erötréninggel aktív PM-es betegeknél két esetismertetésben és feldolgozásra került Hejazi és mtsai, Mattar és mtsai által $[15,16]$. Az egyik esetismertetésben a PM-es flare-ben szenvedő beteg farmakológiai terápiában is részesült (prednisolon $50 \mathrm{mg} / \mathrm{nap}$ és methotrexat 7,5 $\mathrm{mg} /$ hét). A tornaprogram a felső és alsó végtagokra vonatkozóan tartalmazott erősítő gyakorlatokat, sétát és szoba-kerékpározást (15-20 percig) és ADL-tréninget. A betegnél az izomerő 36 izomcsoportból 22 izomcsoportban javult [15]. A másik esetismertetés 3, perzisztáló PM-ben szenvedő betegrôl számol be, akik kortikoszteroid- és/vagy egyéb immunszuppresszív terápiában is részesültek. A tornaprogramot megelőzően és alatta a betegek stabil farmakológiai terápiában részesültek. A betegek 12 hétig heti két alkalommal felügyelet mellett végzett aerob és izomerösítéses tornaprogramban vettek részt, amely tartalmazott 40 perces izomerôsítéses tréninget és 40 perc aerob sétát futópadon. Mindhárom tesztelt izomcsoportot tekintve minden betegnél javulás mutatkozott. A javulás három betegből kettőnél két izomcsoportot is érintett. $\mathrm{A} \mathrm{VO}_{2 \mathrm{max}}$-érték három betegből kettőnél javult, illetve az SF-36 kérdőív adatai szerint az összes beteg egészsége javult [16]. Mindezek arra utalnak, hogy a torna mint adjuváns terápia biztonságosan használható, kombinálva a farmakológiai terápiával, aktív PM/DM-es betegek esetén, sugallva a jótékony hatást az izomteljesítményre és egészségre. Úgy tünik, hogy a korán bevezetett torna hosszú távon elősegíti a fizikailag aktív életvitelt.

\section{A fizikai aktivitás hatása a vázizomzatra}

Négy vizsgálat értékelte az izmon belüli adaptációt a vázizomzatban állóképességi és aerob gyakorlatok végzése során krónikus PM/DM-ben szenvedő betegek esetén $[6,8,17]$. Mind a négy vizsgálat eredményeként javult a vázizomzatban az aerob kapacitás torna hatására, és ez a javulás összefüggésben volt az izomteljesítmény során jelentkező, szisztémás adaptációra és egészségre való tekintettel.

A multicentrikus, randomizált klinikai vizsgálat során a tornacsoportban jelentősen nőtt az aerob kapacitás 12 hét felügyelet mellett végzett állóképességi torna során, míg változatlan volt a nem tornázók csoportjában. Ezen változások alapján a $\mathrm{m}$. vastus lateralisban a laktátszint csökkent microdyalisis-technikával, amikor is kimerülésig, a $\mathrm{VO}_{2 \max } 65 \%$-áig szoba-kerékpároztak a betegek, és izombiopsziával igazolható volt a fokozott mitokondriá- lis enzimaktivitás (CS és Béta-HAD) a m. vastus lateralisból vett biopsziás mintákban [6]. Fokozott kapillárisdenzitás és az ehhez kapcsolódó gének expressziójának upregulációja igazolódott a kapillárisnövekedést és mitokondriális biogenezist kódoló gének tekintetében, illetve az izom-hipertrófiához, fehérjeszintézishez és citoszkeletális remodellinghez kapcsolódó gének tekintetében a tornacsoportban, míg a kontrollcsoportban nem szinkronizált génreguláció igazolódott. Utánkövetés során a nyílt vizsgálat és esetriport igazolta a csökkent szérumlaktátszintet összehasonlítva a kiindulási értékkel, jelezve a fokozott aerob kapacitást a vázizomzatban aerob torna során [8, 17]. Mindezek arra utalnak, hogy mind az állóképességi, mind az aerob torna krónikus PM/DM-ben szenvedő betegek esetén hasznosak, ugyanis aktiválják az aerob fenotípust az aerob metabolizmusban és izomnövekedésben részt vevő utakat, ami felülírja az izomatrófiához vezető folyamatokat.

Eddigi ismereteink szerint az izmon belüli adaptációt torna hatására PM/DM-es betegek aktív fázisában nem vizsgálták.

\section{A fizikai aktivitás hatása a betegségaktivitásra}

Három vizsgálat értékelte ugyanannak a tornaprogramnak (felügyelet mellett végzett állóképességi torna) a hatását krónikus PM/DM-ben szenvedő betegek betegségaktivitására a következő paraméterekkel: (IMACS) 6-item core set, beteg és orvos globális betegségaktivitás VAS-skálán, MMT-teszt 8 izomcsoporton, HAQ-paraméterek, CK-eredmények és az extraszkeletális aktivitás VAS-skálán [18, 19]. Két randomizált kontroll- és egy kontrollált vizsgálat alapján a betegségaktivitás csökkenését írták le az IMACS-kritériumok alapján a betegek többségében, tekintettel arra, hogy a betegek többsége reszpondernek bizonyult a tornacsoportot illetően, míg a kontrollcsoport egyike sem bizonyult reszpondernek $[6,20]$. Az összes betegnél, akik a randomizált kontrollvizsgálatban részt vettek, csökkent a betegségaktivitás és a $\mathrm{VO}_{2 \max }$ javult. A tornacsoportban 12 héttel az állóképességi torna után az immunválaszban és ER-stressznek megfelelő gének expressziójának downregulációja volt igazolható. Tekintettel arra, hogy a betegek krónikus fázisban voltak, csak néhány gyulladásos sejt volt megfigyelhető a biopsziás mintákban a kiinduláskor és 12 héttel az állóképességi torna után. $\mathrm{A} \mathrm{CD}^{+}$T-sejtek és $\mathrm{CD}^{+} 8^{+}$makrofágok száma nem változott sem a torna-, sem a kontrollcsoportban. Négy vizsgálat értékelte a CK-szintek változását felügyelet mellett végzett állóképességi torna, illetve aerob torna esetén $[6,17,20]$. Három vizsgálatban a betegek többségénél a tornacsoportban a kiindulási értékeknél alacsonyabb CK-szintek voltak észlelhetők [6, 17, 20]. Összességében ezek az eredmények azt igazolják, hogy a felügyelet mellett végzett állóképességi torna csökkenti a betegségaktivitást, 
a CK-szinteket, illetve az inflammatorikus válaszban szereplő gének szuppresszióját okozza.

Három vizsgálat értékelte a hatékonyságot a nekroenzimek vizsgálatával felügyelet mellett végzett kombinált aerob és erősítéses torna során PM/DM-es betegekben, akut fázisban és ellenállással szemben otthon végzett torna hatékonyságát jelenlegi akut kezdetû PM/DMben $[7,15,16]$. Ebben a randomizált kontrollvizsgálatban a torna hatékonyságát a szérum-CK-szintek és biopsziás minták elemzésével értékelték. A diagnózis idején a betegeknek jelentősen emelkedettek voltak a CK-szintjei, a torna kezdetének idejére többségében ez normalizálódott. Az izombiopsziás minták vizsgálata során 24 héttel a kiindulás után a gyulladásos infiltrátum kevesebb volt a kiinduláshoz képest mind a két csoportban [7]. Ezek az eredmények megerősítik, hogy a kontrollált torna a farmakológiai terápiákkal kombinálva biztonságos a PM/DM-ben szenvedó betegek esetén a betegség akut fázisában.

Összességében ezek az eredmények arra utalnak, hogy a fizikai aktivitás csökkenti a betegségaktivitást PM/ DM-es betegek esetén, illetve az állóképességi és aerob torna hatékonyabb lehet a betegségaktivitás csökkenésében, mint az erősítéses, illetve rezisztenciagyakorlatok krónikus PM/DM-es betegek esetén. A fizikai aktivitás potenciálisan csökkenti a betegségaktivitást az aktív myositises esetekben. Összességében azt javasoljuk, hogy az adaptált felügyelet mellett végzett torna a gyógyszeres terápia kiegészítéseként használandó az öszszes betegségfázisban az izomteljesítmény, az aerob kapacitás, az egészség maximalizálása céljából, illetve szükséges minimalizálni a kortikoszteroidterápia mellékhatásainak kockázatát. Úgy tûnik, hogy az állóképességi gyakorlatok hozzájárulnak a fokozott izomteljesítményhez, az egészséghez, a csökkent betegségaktivitáshoz, amely krónikus PM/DM-ben szenvedó betegek esetén potenciálisan a vázizomzatban fokozott aerob kapacitás által mediált. A felügyelet mellett végzett torna hatásosabbnak bizonyult az otthoni tornaprogramoknál, de a betegség kezdetén bevezetett, telefonos kontroll mellett végzett otthoni torna is javíthatja hosszú távon a fizikailag aktív életminőséget. A hatékonyság tanulmányozásához további randomizált kontrollvizsgálatok szükségesek.

\section{Következtetések}

A jelenleg publikált kontrollált és randomizált kontrollvizsgálatok igazolták az aerob/állóképességi torna hatékonyságát, mint javult izomteljesítmény és egészség krónikus PM/DM-es betegekben. A rövid távú állóképességi tornaprogramnak hosszú távú hatékonysága bizonyított az izomerőre, azonban, ha a beteg abbahagyja a tornát, a hatékonyság idővel csökken. A fizikai aktivitás izmon belüli adaptációhoz vezet, mint fokozott aerob kapacitás, amelynek háttere a fokozott kapillárisdenzitás és mitokondriális kapacitás. Úgy túnik, hogy ezeknél a betegeknél a fizikai aktivitás csökkenti a betegségaktivitást. A szisztémás hatások, mint a fokozott maximális $\mathrm{O}_{2}$-felvétel, úgy túnik, szorosan kapcsolódnak a csökkent betegségaktivitáshoz és egészséghez, utalva a torna lehetséges betegségmódosító hatására. Evidencia támasztja alá a torna biztonságosságát gyógyszeres terápiában részesülő aktív IIM-es betegek esetén. A torna hatásos az izomteljesítményre, aerob kapacitásra és az egészségre, és csökkenti a betegségaktivitást aktív PM/ DM-es betegekben. IBM-ben hiányoznak a randomizált kontrollvizsgálatok erre vonatkozóan.

Összességében, az állóképességi és aerob torna mind a szisztémás, mind az izmon belüli lokális adaptációhoz hozzájárul krónikus PM/DM-es betegekben, arra utalva, hogy a felügyelet mellett végzett torna alapvetó az izomteljesítmény fejlesztésében és egészség javításában aktív PM/DM-ben szenvedő betegek esetén.

$\mathrm{Az}$ izmon belüli adaptáció az állóképességi tornához analízise újabb adatokkal szolgál a terápia hatékonyságának és azoknak a mechanizmusoknak a megértéséhez, amelyek szerepet játszanak a tartós izomkárosodás javulásában gyógyszeres terápiában részesülő krónikus PM/ DM-es betegekben, de a jövőben további vizsgálatok szükségesek az optimális tornaprogram definiálásához aktív és krónikus IIM-es betegek esetén.

Myositises betegek kiegészítő terápiájaként a torna és a fizioterápia biztonságosnak és hatékonyak tűnik. Az optimális beavatkozás azonban nem tisztázott.

Anyagi támogatás: A közlemény megírása anyagi támogatásban nem részesült.

A cikk végleges változatát a szerző elolvasta és jóváhagyta.

Érdekeltségek: A szerzőnek nincsenek érdekeltségei.

\section{Irodalom}

[1] Hengstman, G. J., van den Hoogen, F. H., van Engelen, B. G.: Treatment of the inflammatory myopathies: update and practical recommendations. Expert Opin. Pharmacother., 2009, 10(7), 1183-1190.

[2] Harris-Love, M. O., Shrader, J. A., Koziol, D., et al.: Distribution and severity of weakness among patients with polymyositis, dermatomyositis and juvenile dermatomyositis. Rheumatology (Oxford), 2009, 48(2), 134-139.

[3] Zong, M., Lundberg, I. E.: Pathogenesis, classification and treat ment of inflammatory myopathies. Nat. Rev. Rheumatol., 2011, 7(5), 297-306

[4] Loell, I. Lundberg, I. E.: Can muscle regeneration fail in chronic inflammation: a weakness in inflammatory myopathies? J. Intern. Med., 2011, 269(3), 243-257.

[5] Cortese, A., Machado, P., Morrow, J., et al.: Longitudinal observational study of sporadic inclusion body myositis: implications for clinical trials. Neuromuscul. Disord., 2013, 23(5), 404-412.

[6] Alemo Munters, L., Dastmalchi, M., Katz, A., et al.: Improved exercise performance and increased aerobic capacity after endurance training of patients with stable polymyositis and dermatomyositis. Arthritis Res. Ther., 2013, 15(4), R83. 
[7] Alexanderson, H., Munters, L. A., Dastmalchi, M., et al.: Resistive home exercise in patients with recent-onset polymyositis and dermatomyositis - a randomized controlled single-blinded study with a 2-year followup. J. Rheumatol., 2014, 41(6), 1124-1132.

[8] Bertolucci, F., Neri, R., Dalise, S., et al.: Abnormal lactate levels in patients with polymyositis and dermatomyositis: the benefits of a specific rehabilitative program. Eur. J. Phys. Rehabil. Med., 2014, 50(2), 161-169.

[9] Wiesinger, G. F., Quittan, M., Nubr, M., et al.: Aerobic capacity in adult dermatomyositis/polymyositis patients and healthy controls. Arch. Phys. Med. Rehabil., 2000, 81(1), 1-5.

[10] Someya, F., Mugii, N.: Limitations to the 6-minute walk test in dermatomyositis with interstitial lung disease in comparison with idiopathic interstitial pneumonia. Clin. Med. Insights Circ. Respir. Pulm. Med., 2013, 7, 1-6.

[11] Cox, F. M., Reijnierse, M., van Rijswijk, C. S., et al.: Magnetic resonance imaging of skeletal muscles in sporadic inclusion body myositis. Rheumatology (Oxford), 2011, 50(6), 1153-1161.

[12] Habers, G. E., Takken, T.: Safety and efficacy of exercise training in patients with an idiopathic inflammatory myopathy - systematic review. Rheumatology (Oxford), 2011, 50(11), 2113-2124.

[13] Nader, G. A., Dastmalchi, M., Alexanderson, H., et al.: A longitudinal, integrated, clinical, histological and mRNA profiling study of resistance exercise in myositis. Mol. Med., 2010, 16(11-12), $455-464$.

[14] Alexanderson, H., Lundberg, I. E.: Exercise as a therapeutic modality in patients with idiopathic inflammatory myopathies. Curr. Opin. Rheumatol., 2012, 24(2), 201-207.
[15] Hejazi, S. M., Engkasan, J. P., Qomi, M. S.: Intensive exercise and a patient in acute phase of polymyositis. J. Back Musculoskelet. Rehabil., 2012, 25(4), 231-234.

[16] Mattar, M. A., Gualano, B., Roschel, H., et al.: Exercise as an adjuvant treatment in persistent active polymyositis. J. Clin. Rheumatol., 2014, 20(1), 11-15.

[17] Dalise, S., Bertolucci, F., Simonella, C., et al.: Intensive aerobic training improves motor performances and oxidative metabolism efficiency in chronic polymyositis: a case report. Neuromuscul. Disord., 2012, 22(Suppl. 3), S221-S225.

[18] Isenberg, D. A., Allen, E., Farewell, V., et al.: International consensus outcome measures for patients with idiopathic inflammatory myopathies. Development and initial validation of myositis activity and damage indices in patients with adult onset disease. Rheumatology (Oxford), 2004, 43(1), 49-54.

[19] Miller, F. W.: New approaches to the assessment and treatment of the idiopathic inflammatory myopathies. Ann. Rheum. Dis., 2012, 71(Suppl. 2), i82-i85.

[20] Alemo Munters, L., Dastmalchi, M., Andgren, V., et al.: Improvement in health and possible reduction in disease activity using endurance exercise in patients with established polymyositis and dermatomyositis: a multicenter randomized controlled trial with a 1-year open extension followup. Arthritis Care Res. (Hoboken), 2013, 65(12), 1959-1968.

(Váncsa Andrea dr., Debrecen, Kassai u. 26., 4028 e-mail: andrea.vancsa@gmail.com)

\section{Tisztelt Szerzőink, Olvasóink!}

Az Orvosi Hetilapban megjelenő/megjelent közlemények elérhetőségére több lehetőség kínálkozik.

Rendelhető különlenyomat, melynek áráról bővebben a www.akkrt.hu honlapon (Folyóirat Szerzőknek, Különlenyomat menüpont alatt) vagy Szerkesztőségünkben tájékozódhatnak.

A közlemények megvásárolhatók pdf-formátumban is, illetve igényelhetö Optional Open Article (www.oopenart.com).

Adott dij ellenében az online közlemények bárki számára hozzáférhetök honlapunkon (a közlemények külön linket kapnak, így más oldalról is linkelhetővé válnak).

Bővebb információ a hirdetes@akkrt.hu címen vagy különlenyomat rendelése esetén a Szerkesztőségtől kérhető. 